\title{
KRITIK ADAM SMITH TERHADAP MERKANTILISME
}

Dian Septiani (90100118025)

\section{dianseptiani806@gmail.com}

Adam Smith, sebagaimana dikatakan di muka, selain menulis buku ekonomi dan moral juga menulis buku tentang astronomi. Kalau kita lihat, ternyata sebagai seorang pemikir dia memiliki pandangan yang berbeda ketika memberikan eksplanasi dan argumentasi atas pokok soal yang berbeda. Di dalam Theory of Moral Sentiment dan Astronomy, Adam Smith dalam eksplanasinya masih berlindung pada nama Tuhan; sedangkan di dalam the Wealth of Nations, dia sama sekali tidak memberikan eksplanasi teologis. Bagi Adam Smith, menurut Andy Denis, aktivitas ilmiah memiliki tujuan dan kecenderungan yang jelas, yakni rekonsiliasi dengan apa yang ada. Ilmu sebagai sebuah usaha retoris. Tujuan sistem pemikiran bukanlah untuk mengungkap kebenaran tentang bagaimana dunia ada, namun untuk menyejukkan imajinasi, yang sebelumnya dihasut oleh kekaguman terhadap keajaiban dunia. Ilmu, bagi Adam Smith, berangkat dari fenomenamengkontraskan sejumlah fenomena dengan fenomena lainnya. Ilmu tidak mampu mencapai realitas yang sesungguhnya.(Ekonomi and Smith 2016)

Karir dan Karya Intelektual Adam Smith, ia lebih banyak menghabiskan karier semasa hidupnya hanya di dua kota, Edinburgh dan Glasgow. Pertama kali ia memulai menguliahi umum adalah di kota Edinburgh di bawah bimbingan Lord Kames. Kemudian ia diangkat sebagai Profesor untuk Logika pada Universitas Glasgow. Setahun setelah pengangkatan tersebut Smith diangkat menjadi Profesor Filsafat Moral.(Hidayatullah 2018)

Menurut Adam Smith kepentingan pribadi (self interest) merupakan kekuatan pengendali perekonomian. Semua proses yang dijalankan akan menuju kearah kemakmuran bangsa, seolaholah setiap individu didorong oleh "tangan gaib" (the invisible hand) yang mendorong mereka maju.9 Dalam bukunya The Wealth on Nation, Adam Smith menyatakan: "Every individual endeavors to employ his capital so that its produce may be of greatest value. He generally neither intends to promote the public interest nor knows how much he is promoting it. He intends only his own security, only his own gain. And he is inthis led by an Invisible Hand to promote an end which was no part of his own intention. By pursuing his own interest he frequently promotes that of society more effectually then when be really inteds to promote it "Setiap individu berusaha untuk menggunakan modalnya sehingga diperoleh hasil yang setingi-tingginya. Dia pada umumnya 
tiaklah bermaksud untuk menunjang kepentingan umum dengan perbuatannya itu, dan pula ia tidak tahu sampai seberapa jauhkan penunjangnya itu. Ia berbuat itu hanyalah untuk kepentingan sendiri, hanya untuk keuntungannya sendiri. Didalam hal ini ia dibimbing oleh suatu "Tangan Gaib" untuk mencapai sesuatu yang menjadi tujuan utamanya. Dengan mengejar kepentinga pribadi seperti itu, ia akan mendorong kemajuan masyarakat dengan dorongan yang seringkali bahkan lebih efektif daripada kalau ia memang sengaja melakukannya.(KAH 2012)

Memang berkembangnya ekonomi sudah dipersiapkan juga beberapa puluh tahun sebelum pecahnya Revolusi Perancis tersebut. Misalnya paham physiocratisme (abad ke-17) yang mengatakan bahwa pertanian adalah dasar dari produksi negara maka seluruh perhatian dicurahkan untuk memperbesar hasil pertanian. Kemudian lahir pula paham Mercantilisme (abad ke-16 - ke-18) yang mengatakan bahwa perdagangan lebih penting daripada perhatian pertanian. Oleh sebab itu, pemerintah harus membulatkan perhatiannya mencari perdagangan dengan negara-negara lain. Selama masa tersebut, usaha-usaha ekonomi masih disangkutkan oleh pimpinannya kepada negara. Rakyat masih merasa tidak senang cara yang demikian. Mereka ingin setiap orang bebas mempunyai usaha dan mempunyai hak milik, serta bebas pula mengatur usaha dan dhak miliknya.(Kajian and Ekonomi, n.d.) 


\section{DAFTAR PUSTAKA}

Ekonomi, Filsafat, and Adam Smith. 2016. "Filsafat Ekonomi Adam Smith.” Jurnal Filsafat 19 (1): 1-22. https://doi.org/10.22146/jf.3447.

Hidayatullah, Indra. 2018. "Pandangan Ibnu Khaldun Dan Adam Smith Tentang Mekanisme Pasar.” Iqtishoduna 7 (1): 117-45. https://www.iaisyarifuddin.ac.id/ejournal/index.php/iqtishoduna/article/view/211.

KAH, Rustam Dahar. 2012. “Teori Invisible Hand Adam Smith Dalam Perspektif Ekonomi Islam.” Economica: Jurnal Ekonomi Islam 2 (2): 57-70. https://doi.org/10.21580/economica.2012.2.2.850.

Kajian, Sebuah, and Filsafat Ekonomi. n.d. "Perspektif Beberapa Ideologi ... Hj. Rabiatul Adawiah 173," 173-86. 